\title{
USING BIOPHYSICAL METHODS IN SHEEP BREADING
}

\author{
Larisa Skorykh $^{1}$, Michael Afanasyev ${ }^{2}$, Vasiliy Kisyuk ${ }^{2}$, Nina Konik ${ }^{3}$ \\ ${ }^{1}$ All-Russian Research Institute of Sheep and Goat Breeding, Russian Federation; \\ ${ }^{2}$ Stavropol State Agrarian University, Russian Federation; \\ ${ }^{3}$ Saratov state agrarian university named after N.I. Vavilov, Russian Federation \\ segwan@ramble.ru, scopush@gmail.com
}

\begin{abstract}
The offered method has been developed for studying biological factors of efficiency of livestock product production. The convergence of biophysical and ethological methods to study allows assessing the quality of animals, productivity of forages and the state of the environment in comparable terms of energy consumption for exponential functions of external behavior. For solution of the task, paramount importance is the selection of vital, free-registered natural indicators having the relationship with the metabolic processes. The article presents the research in the effect of low-intensity laser radiation on biologically active points of tissues and young sheep's organs. The range of exposure laser radiation on animals is identified (single and double in the thymus area). The positive effect of laser radiation on the growth, development and immune reactivity of young sheep is revealed. This is confirmed by the large body weight, more growing capacity in all studied periods of ontogenetic development and more advanced factors about natural protection of the experimental animals. The effect of the influence of laser puncture on the organism of young sheep to increase meat productivity and resistance is proved.
\end{abstract}

Keywords: low-intensity laser radiation, young sheep, lambs.

\section{Introduction}

Historically, domestication and use of conventional livestock breeding techniques have been largely responsible for the increases in yield of livestock products that have been observed over recent decades [1]. At the same time, considerable changes in the composition of livestock products have occurred. If the past changes in demand for livestock products have been met by a combination of conventional techniques, such as breed substitution, cross-breeding and within-breed selection, the future changes are likely to be met increasingly from new techniques [2].

The study factors that can influence the formation of animal productivity and improve the quality of livestock products are highly relevant. One of such factors is studying the influence of biophysical methods, in particular, the impact onto acupuncture points in animals with a laser beam [3]. Low level laser therapy has been used approximately for 25 years and is one of the most underestimated therapies in veterinary and human medicine. One of the primary reasons for its slow acceptance has been the use of a plurality of laser types, which has led to widely differing study results [4].

The long-known fact that laser light can be converted directly into the cellular energy, ATP, was reconfirmed by Michael Hamblin of the Harvard Medical School and the Massachusetts Institute of Technology (MIT), after this laser effect was originally discovered in the 70s by T. Karu and U. Warncke [5].

Acupuncture and LLLT are separate treatment modalities, but the synthesis of these two very effective therapies allows local healing of diseased tissue with LLLT supported by acupuncture as an autonomous regulating therapy. It is important to emphasize that the resulting "laser acupuncture" not only means the stimulation of the acupuncture point by the laser beam instead of the needle, but that the local tissue healing effect of increased ATP production by laser light supplements acupuncture as an integral part of the therapy. Acupuncture and local laser therapy are two therapies of equal value, each very effective by itself that in combination lead to a total holistic therapy approach [6].

Acupuncture has become an effective therapy for many different disorders in both human and veterinary medicine. It is an important component of traditional Chinese veterinary medicine (TCVM), which is an entire system of disease diagnosis and treatment based on 3000 years of tradition, experience and research since the time of Sun Yang (Bo Le), the father of veterinary acupuncture. The Channels and TCVM functional cycles play fundamental roles and are responsible for the smooth transport of $Q i$ (e.g., the sum total of the substances and physiological activities of the body). The current understanding of conventional anatomy and physiology can be useful to increase the understanding of the ancient TCVM concepts. One form of $Q i$ from a conventional perspective is adenosine triphosphate (ATP) produced by the citric acid cycle (tricarboxylic acid and Krebs cycle) 
responsible for aerobic respiration within the mitochondria of the body. Aerobic respiration produces ATP that provides the body with energy $(Q i)$ for all life processes from the synthesis of enzymes to the relaxation of muscles. In all diseases, there is a disturbance of the optimum flow of Qi that results in a loss of balance between Yin (e.g., the parasympathetic nervous system) and Yang (e.g., the sympathetic nervous system) [7].

In economic terms, the use of the laser technology in the livestock industry onto an early period of ontogenesis for implementing genetic productive qualities is the most effective. The efficiency of the laser beam is measured primarily by multiple strengthening of the immune system influencing the productivity of animals. The effect of the laser beam onto an area of biologically active points, responsible for thymus innervation, mobilizes the immune system and contributes to the mobilization of immunodefence of an animal [8-12]. However, in sheep breeding, the low-level laser radiation mechanism has been poorly studied. Therefore, studying the impact onto acupuncture points of the young sheep for meat productivity and resistance causes scientific interest.

\section{Materials and methods}

The objects of the research were young sheep, three groups of 10 animals each: group I - single irradiation at 2 months of age; group II - double exposure with an interval of one month (2 and 3 months of age); group III - control, without using radiation. Low-level laser radiation carried out onto a nervous center, located in the region at the first thoracic vertebra and in charge of thymus innervation, plays an important role for animal immunodefence. Duration of exposure to the region was one minute. For low-level laser radiation the device brand STP near-infrared spectra was used. Taking of blood samples from jugular vein were in the morning hours before feeding. In the blood samples the indicators of resistance (bactericidal and lysozyme activity of blood serum, phagocytic activity of leukocytes) were detected $[3 ; 13]$.

Laser Selection. There are 2 types of lasers based on wave production: continuous wave (cw) or impulse (pulsed) wave. The continuous wave (cw) laser (Figure 1) has a continuous output of power. As an example, class 3B lasers (cw) would have a continuous wave output of 30-500 mW (milliwatt) (Figure 2) and class 4 (cw) would have a continuous wave output of 1-8W (watt). In the second type of laser, the impulse laser, also named pulsed laser or superpulsed laser (Figure 3), the laser energy is emitted in the form of single very strong light pulses.

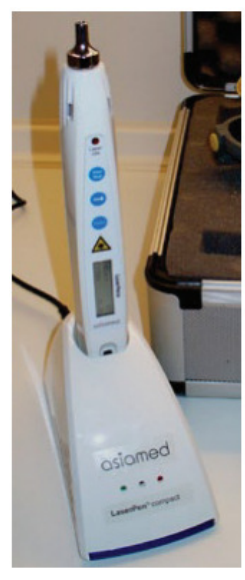

Fig. 1. Laserpen (70 $\mathbf{m W}, 785$ nm, cw laser), Reimers \& Janssen, Berlin, Germany

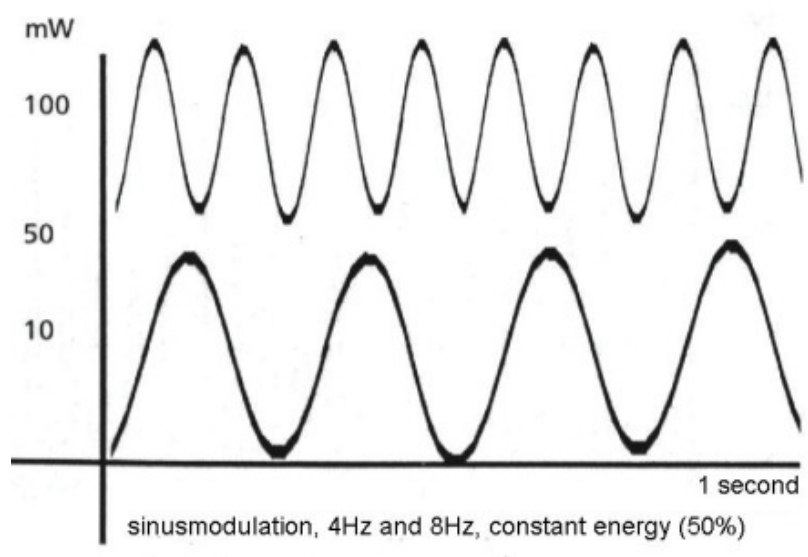

Fig. $2.8 \mathrm{~Hz}$, oscillating between $50 \mathrm{~mW}$ and $100 \mathrm{~mW}$; $4 \mathrm{~Hz}$ oscillating between 0 and $50 \mathrm{~mW}$

The individual light pulses have power spikes from 30-100W, about 1000 times more power output than a continuous wave laser in the same class. The emitted high energy pulses, however, are of very short duration, only 200 nano-seconds each (Figure 4). These quick high pulses of energy provide much greater tissue penetration by the laser light, but due to the short duration of the light flashes, even at high pulse frequencies of modern lasers (up to $40,000 \mathrm{~Hz}$ ), no thermal or even coagulating effect in tissue has been seen. This has the great advantage of deep tissue penetration without emitting so much energy that it heats up or burns the tissue at the surface as may occur in continuous wave lasers $[14 ; 15]$. 


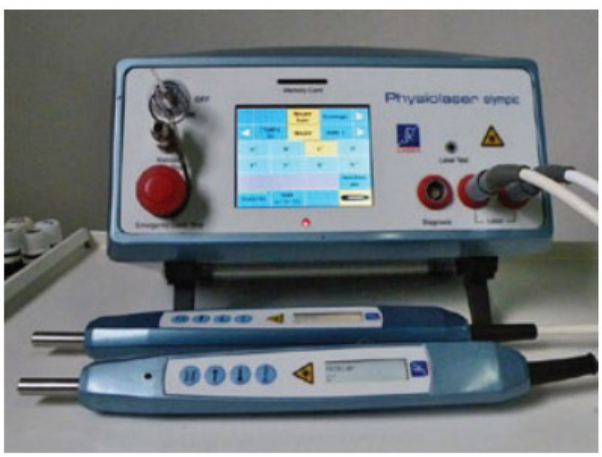

Fig. 3. Physiolaser $(2 \times 90$ Watt, $904 \mathrm{~nm}$, impulse lasers), Reimers \& Janssen, Berlin, Germany

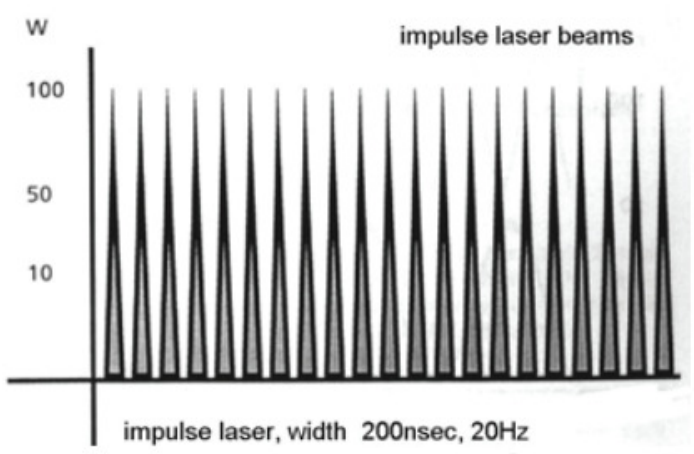

Fig. 4. Impulse laser with 100 Watt pulse peak power (the width actually is smaller than shown in the figure)

\section{Results and discussion}

A comparative analysis of the live weight, while forming the lambs into the groups and in 2 months of age, had not shown any significant differences of the studied indicators. However, in 3 months of age after low-level laser radiation the lambs of the experimental groups I and II $(4.0 ; 4.6 \%)$ were superior by the live weight over control. In the following age period, by the live weight, the differences between the experimental and control groups of animals increased and in 4.5 months of age are $12.4 ; 14.6 \%$; in 6.5 months of age $-12.5 ; 14.7 \%$ (Table 1 ).

The revealed trend by the advantages of the experimental animals by the live weight was and remains by average daily gain. The greatest energy growth had lambs from I and II groups, they were surpassing the animals from the control group from 3 to 4.5 months of age by 8.7 and $18.6 \%$ in the period from 4.5 to 6.5 months of age -13.0 and $15.3 \%$.

Productive indicators of the studied animals

Table 1

\begin{tabular}{|c|c|c|c|}
\hline \multirow{2}{*}{ Indicator } & \multicolumn{3}{|c|}{ Group } \\
\cline { 2 - 4 } & I & II & III \\
\hline Live weight in 3 months of age, $\mathrm{kg}$ & $24.15 \pm 0.61$ & $24.30 \pm 0.50$ & $23.24 \pm 0.42$ \\
\hline Live weight in 4.5 months of age, $\mathrm{kg}$ & $30.0 \pm 0.95$ & $30.60 \pm 0.60$ & $26.70 \pm 0.53$ \\
\hline Live weight in 6.5 months of age, $\mathrm{kg}$ & $38.13 \pm 1.11$ & $38.90 \pm 0.90$ & $33.90 \pm 1.20$ \\
\hline Slaughter-weight, $\mathrm{kg}$ & $17.3 \pm 1.0$ & $18.1 \pm 0.84$ & $15.1 \pm 1.10$ \\
\hline Slaughter-yield, \% & 46.1 & 47.2 & 45.2 \\
\hline
\end{tabular}

Examination of the animals' productive qualities allows presuming a positive influence of the laser irradiation onto the growth and development of the young sheep from the experimental groups, that checks out by greater live weight, higher energy growth in all of the studied ontogenetic periods, and increase in meat productivity.

Evaluation protective capacity of the studied animals revealed a number of features associated not only with the maturity of the organism at different ontogenesis stages, but, in our opinion, a certain influence of laser puncture. Changing the age indicators of natural resistance in the studied animals revealed a significant superiority of the lambs of the experimental groups to the animals from the control group according to the humoral and cellular activity of the factors reactivity. So, during the whole experiment, the indicator of cellular immunity (phagocytic activity of leukocytes) for the experimental animals was more, in 2 months of age by $5.6 \%$ and $8.6 \%$ in 3 months of age - 13.8$18.4 \%$, and 4.5 months of age - by $15.5-21.7 \%$, than for the lambs from the control group. Humoral factors (bactericidal and lysozyme activity of blood serum) into lambs' blood from the experimental groups increased in 2 months of age by 5.1 and 5.4 and 4.3-4.5\%, in 3 months of age -4.9 to 8.3 and $16.0-19.4 \%$, in 4.5 month of age $-6.8-15.1$ and 6.3 and $15.0 \%$ with comparison to the animals from the control group (Table 2). 
Table 2: Effect of low-level laser radiation on level of natural resistance

\begin{tabular}{|c|c|c|c|c|}
\hline \multirow{2}{*}{ Indicator } & \multirow{2}{*}{$\begin{array}{c}\text { Age, } \\
\text { months }\end{array}$} & \multicolumn{3}{|c|}{ Group } \\
\cline { 2 - 5 } & 2 & $27.8 \pm 4.30$ & $28.0 \pm 3.90$ & $23.5 \pm 4.80$ \\
\hline \multirow{3}{*}{ Lysozyme activity of blood serum, \% } & 3 & $40.4 \pm 3.60$ & $43.8 \pm 4.0$ & $24.4 \pm 5.90$ \\
\cline { 2 - 5 } & 4.5 & $33.8 \pm 3.30$ & $42.5 \pm 4.50$ & $27.5 \pm 3.90$ \\
\cline { 2 - 5 } & 2 & $38.8 \pm 4.0$ & $39.1 \pm 4.30$ & $33.7 \pm 3.90$ \\
\hline \multirow{3}{*}{ Bactericidal activity of blood serum, \% } & 3 & $40.4 \pm 3.60$ & $43.8 \pm 4.0$ & $35.5 \pm 4.50$ \\
\cline { 2 - 5 } & 4.5 & $44.4 \pm 5.20$ & $52.7 \pm 4.50$ & $37.6 \pm 3.40$ \\
\hline \multirow{3}{*}{ Phagocytic activity of leukocytes, \% } & 2 & $27.6 \pm 1.20$ & $30.6 \pm 1.40$ & $22.0 \pm 1.0$ \\
\cline { 2 - 5 } & 3 & $37.4 \pm 1.10$ & $42.0 \pm 1.70$ & $23.6 \pm 1.20$ \\
\cline { 2 - 5 } & 4.5 & $42.4 \pm 1.90$ & $48.6 \pm 1.30$ & $26.9 \pm 1.80$ \\
\hline
\end{tabular}

All of the postnatal ontogenesis periods revealed the advantage protective potential of the organism of the lambs from the experimental group that irradiates onto the thymus region. It should be noted that the amplitude of the detected changes does not go beyond the physiological norm. Among the experimental groups of lambs, young sheep twice irradiated into the thymus region have the best protective potential.

\section{Conclusions}

Acupuncture and laser therapy are two separate therapeutic modalities that when combined have a unique synergism. The local effect of the laser with energy supplied in the form of ATP is excellently supplemented by an autonomous regulation of the immune system and stimulation of organ functions by acupuncture.

Summarizing the obtained results it can be concluded that the effect of laser irradiation on the organism of sheep (once and twice onto the thymus region) activates the natural resistance mechanisms to ensure their intensive growth and development.

\section{References}

1. Leakey R., et al. Impacts of AKST (Agricultural Knowledge Science and Technology) on development and sustainability goals. In Agriculture at a crossroads (eds McIntyre B. D., Herren H. R., Wakhungu J., Watson R. T.), Washington, DC: Island Press. 2009, pp. 145-253.

2. Warnke, U. Wie Licht-Energie zu Zell-Energie wird. Ärztliche Praxis Jahrg. No 97, 1987, pp. 3039-3040.

3. Sadovoy, V., Omarov, R., Shlykov, S., Shchedrina, T. Assessment compliance of qualitative food characteristics to standard requirements. 15th International Scientific Conference on Engineering for Rural Development, May 25-27, 2016, Jelgava, Latvia, pp. 360-363.

4. Hamblin MR, Demidova TN. Mechanisms of low level light therapy, Proc. SPIE. 2006, 6140.

5. Karu TI. Photobiological Fundamentals of LowPower Laser Therapy. IEEE Journal od Quantum Electronics QE-23, 1987, pp. 1703-1717.

6. Warnke, U. Der Dioden-Laser, Deutsches Ärzteblatt, No 44, 1987, pp. 2941-2944.

7. Petermann, U. The Components of the Pulse Controlled Laser Acupuncture, PCLAC, AJTCVM, No 7(1), 2012, pp. 57-67.

8. Leakey R., et al. Impacts of AKST (Agricultural Knowledge Science and Technology) on development and sustainability goals. In Agriculture at a crossroads (eds McIntyre B. D., Herren H. R., Wakhungu J., Watson R. T.), Washington, DC: Island Press. 2009, pp. 145-253.

9. Балкова, И.И., Иноземцев В.П., Стравский Я.С., Христофоров В.Н. Лазерное излучение как фактор повышения неспецифической резистентности животных (Laser radiation as a factor to increase of nonspecific resistance of animals). Квантовая терапия в ветеринарии, 2003, P. 11. (In Russian) 
10. Дегтярев Д.Ю., Скорых Л.Н., Киц Е.А. Новые методы терапии в овцеводстве (New methods of treatment in sheep). Овцы, козы, шерстяное дело, 2007, No 4. pp. 75-76. (In Russian)

11. Скорых, Л.Н. Методы и приемы рационального использования генетического потенциала барановпроизводителей отечественной и импортной селекции в товарном овцеводстве (Methods and techniques of rational use genetic potential of sheep producers, local and imported selection into commercial sheep): автореферат дис. доктора биологических наук: 06.02.07 / Ставропольский научно-исследовательский институт животноводства и кормопроизводства. Ставрополь, 2013. (In Russian)

12. Perazzi1 A., Patruno M., Martinello T., Glazar M., Iacopetti I. Effect of MLS Laser Therapy for the treatment of experimentally induced acute tendinopathy in sheep - a preliminary study. Energy for Health, No 14, 2015, pp. 4-7.

13. Никитенко, Е.В., Шумаенко, С.Н., Скорых, Л.Н., Коваленко, Д.В. Влияние лазеропунктуры на естественную резистентность молодняка овец в постнатальном онтогенезе (Influencing laser puncture on natural resistance of lambs during postnatal ontogenesis). Современные тенденции развития науки и технологий, 2016, № 7(1), pp. 4244. (In Russian)

14. Petermann, U. Comparision of Pre- and Posttreatment Pain Scores of Twenty One Horse with Laminitis Treated with Acupoint and Topical Low Level Impulse Laser Therapy, AJTCVM. No 6 (1), 2011, , pp. 13-25.

15. Petermann, U. Pulse Controlled Laser Acupuncture Concept (PCLAC), Textbook for controlled acupuncture, 2007; self-published, www. akupunkturtierarzt.de. 